\title{
FAKTOR-FAKTOR YANG MEMPENGARUHI MOTIVASI BELAJAR SISWA DI ERA PANDEMI COVID-19
}

\author{
Url Jurnal: https://uia.e-journal.id/akademika/article/1271 \\ DOI : https://doi.org/10.34005/akademika.v10i01. 1271
}

Submitted: 2021-02-26 Reviewed: 2021-05-15 Published: 2021-05-30

\author{
Dyah Lukita \\ Universitas Pelita Harapan \\ msluki90@gmail.com
}

\author{
Niko Sudibjo \\ Universitas Pelita Harapan \\ niko.sudibjo@uph.edu
}

\begin{abstract}
The pandemic that is being experienced by all countries, including Indonesia, has made learning activities undergo changes. Learning, which was initially carried out face-to-face, must turn into distance learning. This change has an impact on student motivation. Therefore, this study aims to examine three variables that are considered to have an influence on student learning motivation which are the role of parents while accompanying student learning, teacher creativity in designing and managing learning, and also student interest in learning. This research was conducted with a quantitative approach with the PLS-SEM method on 34 students of grade III SD. The results obtained are the role of parents, teacher's creativity, and interest in learning each have a positive effect on student's learning motivation. The role of parents is the most influential variable.
\end{abstract}

Keywords: Role of parents, teacher's creativity, interest in learning, and student's learning motivation

\begin{abstract}
Abstrak: Pandemi yang sedang dialami oleh semua negara termasuk Indonesia, membuat kegiatan belajar ikut mengalami perubahan. Pembelajaran yang awalnya dilakukan secara tatap muka, harus berubah menjadi pembelajaran jarak jauh. Perubahan ini berdampak pada motivasi belajar siswa. Oleh sebab itu penelitian ini bertujuan untuk meneliti tiga variabel yang dianggap memiliki pengaruh terhadap motivasi belajar siswa, diantaranya peran orang tua selama mendampingi pembelajaran siswa, kreativitas guru dalam merancang maupun mengelola pembelajaran, dan juga minat belajar siswa. Penelitian ini dilaksanakan dengan pendekatan kuantitatid dengan metode PLS-SEM dengan subjek penelitian 34 siswa kelas III SD. Hasil penelitian yang diperoleh adalah peran orang tua, kreativitas guru, dan minat belajar masing - masing berpengaruh positif terhadap motivasi belajar siswa dan peran orang tua menjadi variabel yang paling berpengaruh.
\end{abstract}

Kata kunci: Peran orang tua, kreativitas guru, minat belajar, motivasi belajar siswa

\section{PENDAHULUAN}

Pada Maret 2020, Indonesia mengalami dampak dari virus covid-19 yang juga berpengaruh pada dunia pendidikan. Berdasarkan surat yang diedarkan oleh Mendikbud nomor 4 tahun 2020 tentang tata cara pelaksanaan pendidikan selama masa darurat coronavirus disease (Covid-19), sekolah harus memberlakukan pembelajaran jarak jauh yaitu pembelajaran yang dilakukan secara tatap maya (online). Menurut Kocdar, et al (2018) pembelajaran jarak jauh adalah proses pembelajaran di mana 
individu memiliki kesempatan untuk belajar mandiri dari waktu dan tempat, dan di mana berbagai metode dan teknik digunakan dalam kegiatan pembelajaran.

Namun ternyata pembelajaran jarak jauh memberikan dampak kepada sekolah yaitu adanya penurunan motivasi belajar siswa. Peneliti menemukan hasil survei yang telah dilakukan oleh pihak sekolah pada tiga tahun terakhir, dan ditunjukkan melalui gambar berikut :

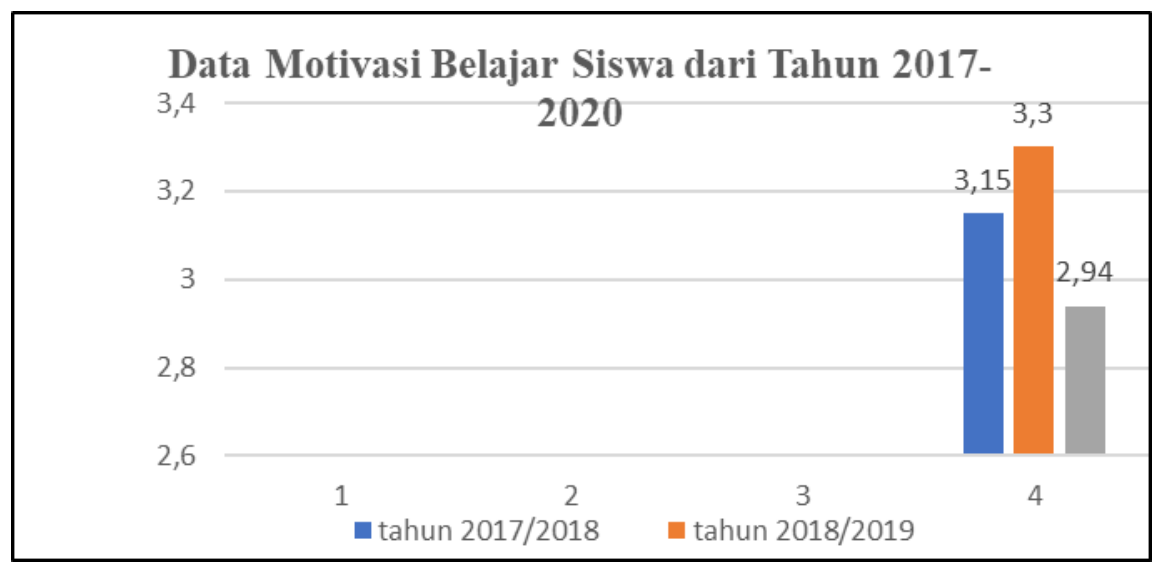

Gambar 1. Data Motivasi Belajar Siswa Tahun 2017-2020

Berdasarkan hasil survei tersebut, didapatkan adanya data penurunan motivasi belajar sebanyak 9 persen atau sebesar 0,36 poin dari skala 4 jika dibandingkan dengan hasil survei tahun sebelumnya. Menurut Slameto (2015) faktor keberhasilan yang dapat mempengaruhi proses pembelajaran, diantaranya adalah adanya faktor internal, faktor eksternal, dan faktor kelelahan. Faktor internal yang dimaksud adalah minat belajar, sedangkan faktor eksternal dapat berupa peran orang tua, dan kreativitas guru dalam mengajar kepada siswa. Siswa yang belum terbiasa untuk memusatkan perhatiannya kepada layar komputer maupun perangkat elektronik lainnya sangat membutuhkan rasa menyenangkan dan ketertarikan dalam mengikuti pembelajaran.

Manusia secara naluriah pastilah memiliki keinginan untuk belajar. Belajar terjadi ketika siswa memiliki minat untuk mengekplorasi rasa keingin tahuannya dan memiliki relevansi dengan kebutuhan dan tujuan dari siswa tersebut. Belajar akan dirasakan bermakna jika muncul dari keinginan siswa tersebut. Keinginan yang mendorong siswa untuk belajar dapat dikatakan sebagai motivasi belajar (Khoe, 2015).

Menurut Ari \& Sri (2017) motivasi merupakan proses internal yang menjadi salah satu faktor penggerak bagi siswa untuk mau melibatkan dan mengarahkan dirinya ke dalam pembelajaran hingga mencapai hasil tertentu. Motivasi siswa dapat digerakkan dari faktor eksternal seperti pemberian materi oleh guru yang disusun secara kreatif, dukungan dari orang tua, sedangkan motivasi dari faktor internal dapat digerakkan dengan adanya minat belajar dari siswa. Motivasi tersebut dapat juga dilihat dari kegiatan belajar. Hal ini juga diungkapkan oleh Astrid (2019) 
yang menyatakan bahwa untuk membentuk motivasi belajar akan dipengaruhi dari faktor keinginan yang ada dalam dirinya sendiri seperti keinginan untuk berhasil maupun adanya rasa kebutuhan dan juga faktor dari luar dirinya seperti dari lingkungan dan suasana belajar yang membentuk sebuah keinginan untuk belajar dan mendapatkan ilmu.

Menurut Sardiman (2018), siswa terlihat memiliki motivasi belajar jika telah menunjukkan beberapa sikap sebagai berikut: semangat dan rajin dalam menghadapi tugas, gigih saat menghadapi kesulitan, menunjukkan minat terhadap bermacam penyelesaian persoalan, tidak mudah jenuh pada tugas yang sama, mampu bertahan ada argumennya apabila sudah merasa yakin pada suatu hal. Seseorang yang memiliki motivasi belajar erat kaitannya jika orang tersebut memiliki motivasi berprestasi. Maka dapat dikatakan bahwa seseorang yang termotivasi akan mengupayakan tindakan dan perhatiannya secara penuh ke dalam pembelajaran, sehingga membuat siswa tersebut dapat berprestasi dan mencapai tujuan yang diharapkan.

Peran orang tua dalam menumbuhkan motivasi belajar siswa kelas III sangatlah penting. Peran orang tua dalam pendidikan anak menurut Gan \& Bilige (2019) dapat diartikan sebagai bentuk bantuan dan dukungan kepada siswa dalam kegiatan belajar mengajar, seperti membantu tugas sekolah, menanggapi prestasi akademik dari siswa, melakukan komunikasi antara orang tua dan guru terkait perkembangan belajar siswa dan menyediakan lingkungan belajar yang mendukung. Menurut Owusu, et al (2018) ada beberapa hal yang dapat menjadi indikator peran orang tua terhadap pembelajaran siswa, diantaranya : bantuan orang tua dengan pekerjaan rumah, diskusi orang tua-anak mengenai masalah yang berhubungan dengan sekolah, mengungkapkan harapan yang tinggi untuk mendorong keberhasilan anak dalam belajar, menyediakan struktur yang kondusif untuk pembelajaran. Pendapat ini diperkuat dari hasil penelitian oleh peneliti sebelumnya yaitu Hendita (2019) dan Fulya (2017) yang menyatakan bahwa keterlibatan dan peran orang tua dalam pembelajaran akan memiliki pengaruh positif terhadap motivasi belajar siswa. Oleh karena itu, dapat diduga peran orang tua berpengaruh positif terhadap hasil belajar siswa.

Selain orang tua, peran guru dalam pembelajaran sangatlah penting. Guru bukan hanya bertugas sebagai pemberi materi, namun diperlukan kreativitas dalam menciptakan dan menyusun seluruh rangkaian proses pembelajaran, seperti perencanaan pengajaran, pelaksanaan pembelajaran dan mengelola kelas, serta melakukan evaluasi pembelajaran. Kreativitas adalah kemampuan yang ada dalam diri seseorang untuk menciptakan dan menghasilkan sesuatu yang baru yang berharga, baik berupa produk, ide, atau gagasan yang baru, kemampuan beradaptasi dengan perubahan dan untuk mewujudkan adanya sebuah perubahan. (MgBoro et al, 2019)

Beberapa ciri yang menunjukkan guru yang kreatif menurut Dalia, et al (2013) yaitu dapat membuat pembelajaran menjadi semakin menarik 
dan efektif serta memiliki ciri dalam mengajar, mampu menggunakan pendekatan imajinatif di dalam kelas, memiliki kepribadian yang mau terus menggali ide baru dan mempraktekkannya, memfasilitasi pengembangan pribadi siswa untuk meningkatkan kreativitasnya, selalu berinovasi dalam pembelajaran dan menciptakan ide baru. Dari penelitian terdahulu yang telah dilakukan, terdapat dua hasil yaitu, Wirandana dan Fitranty (2016) menyatakan kreativitas guru memiliki pengaruh positif terhadap motivasi belajar siswa, begitu juga dengan penelitian yang dilakukan oleh Huriyah (2019) yang menyatakan bahwa kreativitas guru berpengaruh positif terhadap motivasi belajar siswa. Peneliti melihat bahwa guru yang kreatif akan membuat siswa termotivasi, hal itu dapat dibuktikan dari adanya partisipasi aktif dari siswa, dan dorongan untuk mau berinisiatif dalam pembelajaran. Dengan adanya kreativitas, guru akan membuat pembelajaran jarak jauh tetap terasa menyenangkan dan diduga mampu memberikan pengaruh positif kepada peningkatan motivasi belajar.

Motivasi siswa dapat dilihat dari dorongan siswa untuk mau belajar dengan sendirinya. Adanya keinginan siswa untuk belajar juga dapat dipengaruhi jika siswa merasa tertarik akan suatu pelajaran. Ketertarikan itu disebut minat belajar. Slameto (2015) menyatakan bahwa minat belajar adalah sebuah kecenderungan yang tetap untuk memperhatikan dan mengingat beberapa kegiatan, yang disertai rasa senang dan memiliki rasa kepuasan. Pendapat lainnya juga disampaikan oleh Kristiyani (2019) yang menyatakan bahwa minat merupakan kecenderungan dari diri seseorang untuk mau melakukan sesuatu dan dapat terlihat dari perilaku seseorang seperti adanya rasa senang, tertarik serta muncul keinginan untuk berpartisipasi dalam pembelajaran.

Minat belajar memiliki pengaruh yang cukup besar terhadap pembelajaran yang terjadi karena siswa yang tidak suka akan suatu pelajaran tertentu atau penyebab lainnya yang tidak sesuai dengan minat belajarnya, maka siswa tidak akan berusaha sebaik - baiknya terhadap pembelajaran itu. Sedangkan saat siswa merasa tertarik, maka siswa akan menunjukkan perhatian, konsentrasi penuh dan ketekunan terhadap pembelajaran yang dihadapi tanpa mengenal rasa jenuh ataupun menyerah. Pendapat tersebut sesuai dengan penelitian sebelumnya yang dilakukan oleh Umami (2019) dan Azma (2019) yaitu terdapat pengaruh positif antara minat belajar terhadap motivasi belajar siswa. Maka dapat diduga adanya pengaruh positif antara minat dan motivasi belajar.

Variabel dalam penelitian ini, seperti peran orang tua, kreativitas guru, minat belajar dan motivasi belajar adalah diambil menurut persepsi siswa. Persepsi menurut Karwono (2018) adalah interpretasi seseorang akan sebuah situasi, dan bagaimana seseorang melihat sekelilingnya dari caranya sendiri yang tentunya akan berbeda dari orang lain. Maka dapat disimpulkan bahwa hasil penelitian berdasarkan bagaimana siswa menilai, mengamati, dan menginterpretasikan ke dalam pembelajaran hingga akhirnya menafsirkannya hingga membentuk gambaran yang berarti. 
Berdasarkan penjelasan tentang permasalahan yang terjadi dan teori pendukung, maka peneliti tertarik untuk meneliti pengaruh peran orang tua, kreativitas guru dan minat belajar terhadap motivasi belajar siswa kelas III SD XYZ di Kota Jababeka, Bekasi selama pembelajaran jarak jauh. Adapun tujuan penelitiannya adalah untuk mencari apakah tiap variabel eksogen (peran orang tua, kreativitas guru dan minat belajar) berpengaruh positif terhadap motivasi belajar siswa.

\section{METODE}

Penelitian ini termasuk ke dalam penelitian kuantitatif dengan menggunakan metode Partial Least Square Structural-Equation Modeling (PLS-SEM). Metode ini dipilih karena cocok dengan data kecil nonparametrik (Hair et al., 2014). Dalam penelitian ini, terdapat empat variabel, yaitu tiga variabel eksogen yaitu peran orang tua, kreativitas guru, dan minat belajar. Serta satu variabel endogen yaitu motivasi belajar.

Data yang dikumpulkan merupakan hasil dari penyebaran angket atau kuesioner secara online menggunakan google form. Penelitian ini menggunakan teknik sensus sebagai teknik sampelnya, dikarenakan keseluruhan populasi termasuk ke dalam sampel penelitian. Waktu penelitian akan dilakukan selama 16 minggu terhitung dari Juli 2020 sampai November 2020. Subjek penelitian ini terdiri dari 34 responden yang merupakan siswa kelas III dari sekolah SD XYZ di Kota Jababeka.

Penelitian ini menggunakan kuesioner tertutup dengan jawaban yang telah berikan. Sehingga responden dapat memilih langsung pernyataan yang dirasa sesuai. Kuesioner yang dibagian kepada responden bersifat pernyataan tertutup dengan skala Likert. Rentang pilihan jawaban yang disediakan adalah 1 (sangat tidak setuju) hingga 5 (sangat setuju).

Data diperoleh dari instrumen penelitian berupa kuesioner yang diberikan kepada 34 siswa kelas III B, yang terdiri dari 18 siswa laki - laki dan 16 siswa perempuan dengan rentang usia $7-9$ tahun. Selain melihat data dari jenis kelamin dan usia, peneliti juga memperoleh informasi berupa lama belajar siswa dalam satu hari, data pekerjaan ayah dan ibu dari siswa dan waktu pendampingan belajar yang dilakukan orang tua dari responden setiap harinya.

\section{HASIL}

Analisis statistik deskriptif dilihat dari jenis kelamin, usia, pekerjaan ayah, pekerjaan ibu. Berikut rincian profil responden pada tabel data demografi :

Tabel 1. Demografi Profil Responden

\begin{tabular}{clcc}
\hline Data Demografi & Profil Responden & Jumlah & Jumlah (dalam \%) \\
\hline \multirow{2}{*}{ Jenis Kelamin } & Laki - laki & 18 & $53 \%$ \\
& Perempuan & 26 & $47 \%$
\end{tabular}




\begin{tabular}{clcc}
\hline \multicolumn{4}{c}{ Tabel 1. Demografi Profil Responden } \\
\hline Data Demografi & Profil Responden & Jumlah & Jumlah (dalam \%) \\
\hline \multirow{6}{*}{ Usia } & 7 tahun & 3 & $9 \%$ \\
& 8 tahun & 27 & $79 \%$ \\
& 9 tahun & 4 & $12 \%$ \\
& Karyawan & 18 & $53 \%$ \\
& Wekerjaan Ayah & 5 & $15 \%$ \\
& Pedagang & 9 & $26 \%$ \\
& Pertambangan & 2 & $6 \%$ \\
& Pedagang & 3 & $9 \%$ \\
& Kekeryawan & 9 & $26 \%$ \\
& Ibu rumah tangga & 22 & $65 \%$ \\
\hline
\end{tabular}

\section{Model Pengukuran}

Pada analisis statistik inferensial, model Pengukuran yang dilaksanakan pada penelitian ini ada dua evaluasi model yaitu melalui model pengukuran (outer model) yaitu dengan menguji validitas konvergen, validitas diskriminan dan menguji reliabilitas menggunakan composite reliability dan Cronbach's Alpha serta pengujian model struktural atau inner model yang digunakan untuk memastikan model penelitian yang digunakan sudah tepat dan untuk memperkirakan hubungan antar konstruk. Pengujian ini dilakukan dengan melihat nilai dari Variance Inflation Factor (VIF), $R$ Square, serta pengujian path coefficient menggunakan SmartPLS.

\section{Uji Validitas Konvergen}

Pengujian uji validitas konvergen dapat dilakukan menggunakan dua cara, yang pertama adalah dengan menghitung Average Variance Extracted (AVE) dan selanjutnya adalah menghitung loading factor. Tujuan dari penghitungan loading factor adalah untuk mengetahui nilai yang dihasilkan oleh tiap indikator untuk mengukur variabel. Batasan nilai loading factor yang diterima ialah jika ada di atas 0,70 , sedangkan tujuan dari penghitungan AVE yaitu untuk menghitung nilai yang dimiliki dari tiap variabel yang diukur terhadap variabel itu sendiri maupun variabel lainnya. Nilai AVE yang diterima yaitu jika ada di atas 0,50.

Berdasarkan hasil penelitian yang diolah menggunakan SmartPLS didapatkan bahwa 51 butir pertanyaan yang diberikan kepada responden, semuanya memiliki nilai di atas 0,50. Maka didapatkan hasil bahwa setiap item telah mencapai persyaratan dari validitas konvergen. Berikut uji AVE yang akan ditampilkan pada tabel 2 :

Tabel 2. Hasil Uji Validitas Konvergen dengan AVE 


$\begin{array}{cc}\text { X1 (Peran Orang Tua) } & 0.636 \\ \text { X2 (Kreativitas Guru) } & 0.733 \\ \text { X3 (Minat Belajar) } & 0.628 \\ \text { Y (Motivasi Belajar) } & 0.614\end{array}$

Pengecekan uji validitas konvergen selanjutnya dapat dilihat dari penghitungan loading factor, hasil yang diterima adalah jika ada di atas 0,70 . Berikut ini adalah tabel hasil pengolahan data loading factor :

Tabel 3. Hasil Uji Validitas Konvergen dengan Loading Factor

\begin{tabular}{|c|c|c|c|c|}
\hline Item Pernyataan & $\begin{array}{c}\text { X1 (Peran } \\
\text { Orang Tua) }\end{array}$ & $\begin{array}{c}\mathrm{X} 2 \\
\text { (Kreativitas } \\
\text { Guru) }\end{array}$ & $\begin{array}{c}\text { X3 (Minat } \\
\text { Belajar) }\end{array}$ & Y (Motivasi Belajar) \\
\hline X1.PO_01 & 0.901 & & & \\
\hline X1.PO_02 & 0.744 & & & \\
\hline X1.PO_03 & 0.714 & & & \\
\hline X1.PO_04 & 0.859 & & & \\
\hline X1.PO_05 & 0.908 & & & \\
\hline X1.PO_06 & 0.728 & & & \\
\hline X1.PO_07 & 0.707 & & & \\
\hline X1.PO_08 & 0.829 & & & \\
\hline X1.PO_09 & 0.731 & & & \\
\hline X1.PO_10 & 0.835 & & & \\
\hline X1.PO_11 & 0.786 & & & \\
\hline X1.PO_12 & 0.794 & & & \\
\hline X2.KG_01 & & 0.903 & & \\
\hline X2.KG_02 & & 0.858 & & \\
\hline X2.KG_03 & & 0.842 & & \\
\hline X2.KG_04 & & 0.861 & & \\
\hline X2.KG_05 & & 0.905 & & \\
\hline X2.KG_06 & & 0.889 & & \\
\hline X2.KG_07 & & 0.803 & & \\
\hline X2.KG_08 & & 0.879 & & \\
\hline X2.KG_09 & & 0.807 & & \\
\hline X2.KG_10 & & 0.834 & & \\
\hline X2.KG_11 & & 0.874 & & \\
\hline X2.KG_12 & & 0.814 & & \\
\hline X3.MI_01 & & & 0.845 & \\
\hline X3.MI_02 & & & 0.745 & \\
\hline X3.MI_03 & & & 0.83 & \\
\hline X3.MI_04 & & & 0.724 & \\
\hline
\end{tabular}




\begin{tabular}{|c|c|c|c|c|}
\hline Item Pernyataan & $\begin{array}{c}\text { X1 (Peran } \\
\text { Orang Tua) } \\
\end{array}$ & $\begin{array}{c}\mathrm{X2} \\
\text { (Kreativitas } \\
\text { Guru) }\end{array}$ & $\begin{array}{c}\text { X3 (Minat } \\
\text { Belajar) } \\
\end{array}$ & Y (Motivasi Belajar) \\
\hline X3.MI_05 & & & 0.792 & \\
\hline X3.MI_06 & & & 0.816 & \\
\hline X3.MI_07 & & & 0.785 & \\
\hline X3.MI_08 & & & 0.873 & \\
\hline X3.MI_09 & & & 0.836 & \\
\hline X3.MI_10 & & & 0.752 & \\
\hline X3.MI_11 & & & 0.795 & \\
\hline X3.MI_12 & & & 0.77 & \\
\hline X3.MI_13 & & & 0.753 & \\
\hline X3.MI_14 & & & 0.766 & \\
\hline Y.MO_01 & & & & 0.733 \\
\hline Y.MO_02 & & & & 0.871 \\
\hline Y.MO_03 & & & & 0.759 \\
\hline Y.MO_04 & & & & 0.832 \\
\hline Y.MO_05 & & & & 0.759 \\
\hline Y.MO_06 & & & & 0.821 \\
\hline Y.MO_07 & & & & 0.747 \\
\hline Y.MO_08 & & & & 0.75 \\
\hline Y.MO_09 & & & & 0.86 \\
\hline Y.MO_10 & & & & 0.816 \\
\hline Y.MO_11 & & & & 0.732 \\
\hline $\begin{array}{l}\text { Y.MO_12 } \\
\text { Y.MO_13 }\end{array}$ & & & & $\begin{array}{c}0.732 \\
0.76 \\
\end{array}$ \\
\hline
\end{tabular}

Dari hasil pengolahan loading factor, didapatkan bahwa seluruh item pernyataan memiliki nilai di atas 0,70 . Maka dapat dinyatakan bahwa data ini valid dan memenuhi pengujian validitas konvergen.

\section{Uji Validitas Diskiriminan}

Selanjutnya adalah menguji validitas diskriminan, tujuan dilakukannya pengujian ini adalah untuk melihat apakah ada korelasi dari item - item dalam satu variabel. Uji diskriminan dapat dilakukan dengan dua cara yaitu dengan menghitung cross loading dari tiap variabel, yaitu harus melebihi 0,70 serta membandingkan akar kuadrat AVE. Hal ini dinyatakan oleh Ghozali dan Latan (2015) bahwa jika akar kuadrat AVE pada tiap variabel memiliki nilai yang lebih besar dari korelasi antar variabel dalam model maka hal ini menunjukkan validitas diskriminan yang baik. Berikut hasil uji validitas diskriminan pada tabel 4 : 
Tabel 4. Uji Validitas Diskriminan

\begin{tabular}{ccccc}
\hline Variabel & $\begin{array}{c}\text { X1 (Peran } \\
\text { Orang Tua) }\end{array}$ & $\begin{array}{c}\text { X2 (Kreativitas } \\
\text { Guru) }\end{array}$ & $\begin{array}{c}\text { X3 (Minat } \\
\text { Belajar) }\end{array}$ & $\begin{array}{c}\text { Y (Motivasi } \\
\text { Belajar) }\end{array}$ \\
\hline X1 (Peran Orang Tua) & 0.798 & & & \\
X2 (Kreativitas Guru) & 0.754 & 0.856 & & \\
X3 (Minat Belajar) & 0.716 & 0.633 & 0.793 & \\
Y (Motivasi Belajar) & 0.893 & 0.811 & 0.846 & 0.784 \\
\hline
\end{tabular}

Pada uji validitas diskriminan table 4 ini nilai korealasi variabel peran orang tua dengan variabel itu sendiri lebih besar dibandingkan korelasi variabel peran orang tua dengan variabel lainnya. Sama halnya dengan variabel kreativitas guru dan variabel minat belajar yang memiliki nilai lebih besar saat dibandingkan dengan variabel miliknya melebihi saat dibandingkan dengan variabel lainnya.

\section{Uji Reliabilitas}

Pengujian selanjutnya yang dilakukan apabila data sudah teruji valid adalah pengujian reliabilitas, yaitu untuk mengetahui kualitas dari suatu instrument penelitian serta dapat dipertanggung jawabkan. Ghozali \& Latan (2015) menyatakan bahwa tujuan dari pengujian reliabilitas yaitu untuk membuktikan keakuratan, konsistensi dan ketepatan instrumen dalam mengukur konstruk atau variabel.

Peneliti menggunakan smart PLS 3.0 dalam mengukur uji reliabilitas yaitu dengan melakukan penghitungan composite reliability dan cronchbach alpha. Data yang reliabel adalah data yang memiliki nilai composite reliabilitynya lebih dari 0,70 dan nilai cronbach alpha di atas 0,60 . Uji reliabilitas yang dilakukan oleh peneliti dapat dilihat tabel 5 berikut ini :

Tabel 5. Hasil Pengujian Reliabilitas

\begin{tabular}{ccc}
\hline Variabel & Cronbach's Alpha & Composite Reliability \\
\hline X1 (Peran Orang Tua) & 0.947 & 0.954 \\
X2 (Kreativitas Guru) & 0.967 & 0.971 \\
X3 (Minat Belajar) & 0.954 & 0.959 \\
Y (Motivasi Belajar) & 0.947 & 0.954 \\
\hline
\end{tabular}

Berdasarkan hasil dari tabel 5 ditunjukkan bahwa nilai setiap konstruk pada composite reliability dan cronbach's alpha ada di atas 0,70 , yaitu ada di angka 0,90 atau dapat dikatakan berada di nilai yang tinggi dan memenuhi persyaratan. Sehingga data ini dikatakan reliabel.

\section{Uji Multikolinieritas}

Uji multikolinieritas adalah sebuah uji yang berguna untuk melihat adakah korelasi antara variabel eksogen. Ketiga variabel eksogen dalam 
penelitian ini adalah peran orang tua, kreativitas guru dan minat belajar. Ghozali dan Latan (2015) menyatakan bahwa uji multikolinieritas dapat dilakukan dengan cara menghitung nilai Variance Inflation Factor (VIF). Nilai yang diterima atau sudah baik adalah jika lebih kecil dari lima. Uji multikolinieritas disajikan pada Tabel 6 berikut ini :

Tabel 6. Hasil Uji Multikolinierias

\begin{tabular}{|c|c|c|c|c|}
\hline Variabel & $\begin{array}{c}\text { X1 (Peran } \\
\text { Orang } \\
\text { Tua) }\end{array}$ & $\begin{array}{c}\mathrm{X} 2 \\
\text { (Kreativitas } \\
\text { Guru) }\end{array}$ & $\begin{array}{c}\text { X3 (Minat } \\
\text { Belajar) }\end{array}$ & $\begin{array}{l}\text { Y (Motivas } \\
\text { Belajar) }\end{array}$ \\
\hline X1 (Peran Orang Tua) & & & & 2.969 \\
\hline X2 (Kreativitas Guru) & & & & 2.417 \\
\hline X3 (Minat Belajar) & & & & 2.14 \\
\hline Y (Motivasi Belajar) & & & & \\
\hline
\end{tabular}

Berdasarkan ketiga nilai VIF terhadap ketiga variabel pada table 6 di atas ini memiliki nilai kurang dari lima, Sehingga dapat disimpulkan bahwa model penelitian yang dilakukan terhadap motivasi belajar tidak mengalami masalah multikolinieritas.

\section{Uji Kesesuaian Model}

Uji Kesesuaian model yang merupakan bagian dari pengujian inner model juga dilakukan dengan cara melihat besarnya presentase variance yang ditunjukkan pada nilai R-Square untuk konstruk variabel endogen. Berikut hasil nilai R-Square pada tabel 7:

Tabel 7. Hasil Uji Kesesuaian Model (R-Square)

\begin{tabular}{cc}
\hline & R Square \\
\hline Y (Motivasi Belajar) & 0.909 \\
\hline
\end{tabular}

Berdasarkan perhitungan pada tabel 7 tersebut, maka terlihat bahwa motivasi belajar telah dijelaskan dengan sangat baik dengan nilai $R$ Square yaitu sebesar 0,909 atau $91 \%$. Hal itu berarti variabel motivasi belajar sangat dipengaruhi oleh ketiga variabel yang diteliti, seperti peran orang tua, kreativitas guru, dan minat belajar. Namun masih ada pengaruh sebesar $9 \%$ yang masih perlu diteliti lagi di luar dari penelitian yang dilakukan ini. Pengaruh lainnya yang tidak termasuk penelitian ini dapat berupa gaya belajar, kesiapan belajar siswa, maupun kemampuan guru lainnya dalam mengelola pembelajaran, dan lain - lain.

\section{Uji Hipotesis}

Pengujian hipotesis dapat dilakukan dengan melihat besaran nilai koefisien jalur yang dihasilkan. Dengan adanya analisa jalur, peneliti akan dapat menguji hubungan langsung maupun tidak langsung antar variabel di dalam model penelitian. Pada smart PLS, uji hipotesa dilakukan dengan 
mencari nilai path coeficient. Jika nilai koefisiennya menunjukkan nilai di bawah 0, maka hipotesis ditolak, namun jika nilai koefesien jalur lebih besar dari nol maka hipotesis diterima (Ghozali \& Latan, 2015). Berikut hasil uji hipotesis yang ditunjukkan pada tabel 8 :

Tabel 8. Hasil Uji Hipotesis

\begin{tabular}{|c|c|c|c|}
\hline Jalur & Hipotesis & Nilai Koefisien & Hasil \\
\hline $\begin{array}{c}\text { X1 (Peran } \\
\text { Orang Tua) - } \\
>\text { Y (Motivasi } \\
\text { Belajar) }\end{array}$ & $\begin{array}{c}\text { Peran orang tua } \\
\text { berpengaruh positif } \\
\text { terhadap motivasi } \\
\text { belajar siswa kelas } \\
\text { III. }\end{array}$ & 0.444 & $\begin{array}{l}\text { Hipotesis } 1 \text { diterima } \\
\text { dan didukung, } \\
\text { pengaruh positif dan } \\
\text { signifikansinya tinggi. }\end{array}$ \\
\hline $\begin{array}{c}\text { X2 } \\
\text { (Kreativitas } \\
\text { Guru) -> Y } \\
\text { (Motivasi } \\
\text { Belajar) }\end{array}$ & $\begin{array}{c}\text { Kreativitas guru } \\
\text { berpengaruh positif } \\
\text { terhadap motivasi } \\
\text { belajar siswa kelas } \\
\text { III. }\end{array}$ & 0.236 & $\begin{array}{l}\text { Hipotesis } 2 \text { diterima } \\
\text { dan didukung, } \\
\text { pengaruh positif dan } \\
\text { signifikansinya tinggi. }\end{array}$ \\
\hline $\begin{array}{l}\text { X3 (Minat } \\
\text { Belajar) -> Y } \\
\text { (Motivasi } \\
\text { Belajar) }\end{array}$ & $\begin{array}{c}\text { Minat belajar } \\
\text { berpengaruh positif } \\
\text { terhadap motivasi } \\
\text { belajar siswa kelas } \\
\text { III. }\end{array}$ & 0.379 & $\begin{array}{l}\text { Hipotesis } 3 \text { diterima } \\
\text { dan didukung, } \\
\text { pengaruh positif dan } \\
\text { signifikansinya tinggi. }\end{array}$ \\
\hline
\end{tabular}

Ketiga hipotesis tersebut ditunjukkan melalui gambar model hasil pengujian hipotesis sebagai beriku

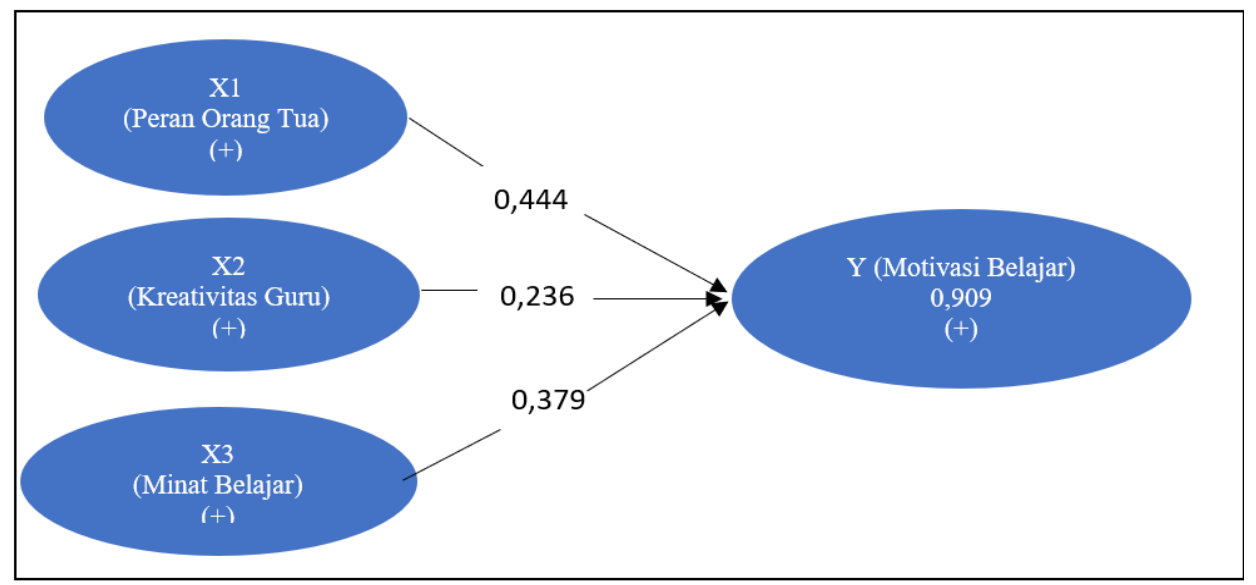

Gambar 2. Model Uji Hipotesis

Dari hasil pengujian hipotesis dengan koefesien jalur pada penelitian ini, maka persamaan regresi dapat dituliskan sebagai berikut :

$$
y=0.444 \times 1+0.236 \times 2+0.379 \times 3
$$




$\begin{array}{lll}\text { an : } & & \\ \mathrm{y} & = & \text { motivasi belajar } \\ \mathrm{x} 1= & \text { Peran orang tua } \\ \mathrm{x} 2 & = & \text { Kreativitas Guru } \\ \mathrm{x} 3 & = & \text { Minat Belajar }\end{array}$

\section{PEMBAHASAN}

\section{Hipotesis 1: Peran orang tua berpengaruh positif terhadap motivasi belajar siswa.}

Hasil uji hipotesis pertama menunjukkan bahwa peran orang tua berpengaruh positif terhadap motivasi belajar. Hal itu ditunjukkan dengan nilai koefisien bernilai positif 0,444 atau sebagai variabel yang paling mempengaruhi terhadap motivasi belajar siswa. Hipotesis pertama ini sesuai dengan penelitian terdahulu oleh Hendita (2019) dan Fulya (2017) yang menyatakan bahwa peran orang tua dalam proses belajar mengajar akan memberikan pengaruh positif terhadap motivasi belajar siswa.

Dalam penelitian ini, ditemukan bahwa nilai pengaruh yang cukup tinggi antara peran orang tua dengan motivasi belajar siswa. Jika dilihat dari observasi saat di lapangan, peneliti juga menemukan bahwa peran orang tua tidak selalu harus merujuk kepada orang tua yang ada di rumah saja. Namun bentuk keterlibatan aktif dalam pembelajaran siswa tetap merupakan bentuk peran dari orang tua. Ada beberapa siswa yang memiliki orang tua yang bekerja di kantor, namun saat terjadi sesuatu saat pembelajaran dan orang tua ini berkontribusi aktif, maka anak tetap merasa termotivasi untuk belajar, sebaliknya walaupun orang tua ada di rumah, namun tidak mau ikut terlibat selama pembelajaran akan ditemukan hasil rendahnya motivasi belajar siswa. Indikasi orang tua dikatakan terlibat atau berperan adalah ketika orang tua komunikatif kepada guru di sekolah, sadar akan apa yang dipelajari anaknya di kelas, mampu menjadi mitra guru dalam memfasilitasi pembelajaran anaknya di rumah, dapat berdiskusi dengan anak-anak mereka tentang kegiatan, peraturan dan aturan yang terkait dengan sekolah, serta memeriksa pekerjaan anak selama pembelajaran di sekolah, seperti pekerjaan rumah, ulangan, tes, dan lain - lain.(Gan\&Bilige, 2019)

\section{Hipotesis 2: Kreativitas guru berpengaruh positif terhadap motivasi belajar siswa.}

Hasil uji hipotesis kedua menunjukkan bahwa kreativitas guru berpengaruh positif terhadap motivasi belajar. Hal itu ditunjukkan dengan nilai koefisien bernilai positif 0,236 . Hipotesis kedua ini sesuai dengan penelitian yang dilakukan Huriyah (2019) yaitu penelitian terhadap 112 siswa kelas XI dan menyatakan bahwa terdapat hubungan positif antara kreativitas guru dengan motivasi siswa dalam belajar bahasa Inggris.

Dari keseluruhan variabel eksogen, jika dilihat dari hasil yang diperoleh maka, dapat dikatakan bahwa variabel kreativitas guru memiliki 
pengaruh yang tidak terlalu tinggi terhadap motivasi belajar. Pendapat ini sesuai dengan penelitian terdahulu oleh Alzoubi, et al (2016) kepada 44 mahasiswa, Hasil penelitian menyatakan bahwa kreativitas guru memiliki pengaruh terhadap motivasi belajar siswa.

Pada pelaksaanaanya di lapangan, peneliti menemukan bahwa memang benar adanya motivasi belajar siswa juga dipengaruhi oleh kreativitas guru, yaitu saat guru memberikan pembelajaran yang menarik, beragam ide dan inovasi yang ditunjukkan dalam pembelajaran. Namun dikarenakan pembelajaran terjadi di rumah masing - masing siswa, atau secara pembelajaran jarak jauh. Maka kapasitas guru dalam menjangkau siswa masih terbatas. Motivasi belajar siswa bukan hanya dipengaruhi oleh kreativitas guru saja, namun masih ada variabel lainnya yang tidak masuk ke dalam penelitian ini, seperti yang dituliskan pada peraturan pemerintah no 74 tahun 2008, yang menyampaikan bahwa kompetensi yang dimiliki guru harus mencangkup kompetensi pedagogik, kompetensi kepribadian, kompetensi sosial dan kompetensi profesional.

\section{Hipotesis 3: Minat belajar berpengaruh positif terhadap motivasi belajar siswa.}

Hasil uji hipotesis ketiga menunjukkan bahwa minat belajar memiliki pengaruh positif terhadap motivasi belajar. Hal itu ditunjukkan dengan nilai koefisien bernilai positif 0,379. Hipotesis ketiga ini didukung oleh penelitian sebelumnya oleh Azma (2019) kepada 261 siswa yang menyatakan ada pengaruh antara minat belajar dengan motivasi belajar.

Dalam pelaksanaan di lapangan, peneliti menemukan bahwa siswa yang minat belajarnya tinggi maka motivasi belajarnya juga tinggi, sebaliknya jika dari awal pembelajaran terlihat minat belajar siswa rendah atau tidak terlihat, maka motivasi belajarnya juga rendah. Hal itu sesuai dengan teori menurut Slameto (2015) yang menyatakan bahwa minat belajar sebagai sebuah kecenderungan yang tetap untuk mau memperhatikan dan mengingat beberapa kegiatan, disertai rasa senang dan memiliki kepuasan terhadap kinerjanya, dan indikator minat belajar siswa ditunjukkan dari siswa yang tertarik untuk mencari sebanyak banyaknya pengetahuan tentang hal yang diminati, tidak mudah bosan, dan mau lebih banyak terlibat pada kegiatan yang diminati. (Renninger, 2015)

Dari hasil yang ditemukan sesuai uji hipotesis, benar adanya bahwa minat yang merupakan faktor internal dari terbentuknya motivasi akan memegang peranan yang penting, hal ini ditunjukkan dari nilai koefisien yang tinggi setelah adanya peran orang tua.

Penelitian ini telah dijalankan berdasarkan prosedur penelitian yang telah diterapkan. Tetapi masih ada beberapa keterbatasan dalam pelaksanaan penelitian ini yang membuat penelitian masih belum sempurna, diantaranya yaitu :

1) Keterbatasan usia responden, penelitian ini dilakukan kepada siswa yang masih berusia 7 - 9 tahun. Usia yang masih terlalu muda untuk 
dijadikan subjek penelitian, apalagi peneliti yang juga sebagai guru kelas dari responden harus memberikan kepercayaan kepada guru lain untuk membantu dalam pelaksanaan pengambilan data. Sehingga diperlukan waktu yang lebih untuk mengutarakan pemikiran peneliti kepada guru tersebut yang akhirnya harus dapat diutarakan kepada siswa saat menjadi responden penelitian. Dengan usia responden yang masih mudah, membuat peneliti harus membuat pernyataan yang lebih mudah dimengerti oleh siswa, jadi jika ada pernyataan yang mungkin belum sepenuhnya dimengerti oleh siswa akan membuat penelitian kurang sempurna.

2) Keterbatasan jarak, dengan adanya pandemi yang menyebabkan pembelajaran dan penelitian dilaksanakan secara jarak jauh. Maka peneliti agak kesulitan dalam memberikan lembar kuesioner. Kuesioner yang dibuat dalam bentuk google form, kadang masih mengalami kendala dalam pengisiannya, seperti jaringan, dan faktor teknis lainnya.

Peneliti mengharapkan penelitian ini dapat menjadi masukan dan memberikan solusi kepada pihak sekolah untuk mampu meningkatkan lagi motivasi belajar pada siswa. Sekolah harus menunjukkan adanya komunikasi serta sinergi yang baik antara orang tua dan sekolah, baik dengan komunikasi aktif melalui aplikasi chatting online, maupun meminta keterlibatan aktif orang tua dalam proses pembelajaran anak, seperti hadir ke dalam acara pengambilan rapor, acara sekolah, maupun evaluasi pembelajaran setiap minggunya. Selain itu, sekolah juga perlu memfasilitasi guru agar dapat membagikan pengetahuan dan kreativitasnya sehingga mampu meningkatkan kreativitas guru dalam merancang pembelajaran. Guru juga perlu melakukan pendekatan kepada siswa untuk mampu merangsang minat belajar di dalam diri siswa, yang nantinya akan memberikan dampak pada motivasi belajar siswa.

\section{KESIMPULAN}

Berdasarkan hasil analisis terhadap variabel - variabel dalam penelitian ini yaitu peran orang tua, kreativitas guru, minat belajar dan motivasi belajar, maka dapat disimpulkan bahwa terdapat pengaruh positif peran orang tua terhadap motivasi belajar siswa. Hasil penelitian ini dapat dijadikan oleh sekolah sebagai masukan dalam pengambilan keputusan terkait dengan usaha perbaikan dan juga peningkatan terhadap motivasi belajar siswa. Peningkatan dan perbaikan tersebut, harus dilihat dari kerja sama antara sekolah dan orang tua, dikarenakan adanya pengaruh positif antara peran orang tua dengan motivasi belajar siswa. Selain itu didapatkan hasil bahwa kreativitas guru berpengaruh positif terhadap motivasi belajar siswa. Hal ini menunjukkan bahwa adanya perbaikan penerapan kreativitas guru, seperti adanya pelatihan terhadap guru dalam pengembangan materi dan teknik dalam mengajar serta adanya 
lingkungan yang memadai untuk guru dapat membagikan pengalaman dan berbagi pengetahuan tentang kreativitas dalam mengajar akan mempengaruhi tingginya motivasi belajar siswa. Terakhir didapatkan hasil bahwa minat belajar siswa berpengaruh positif terhadap motivasi belajar siswa. Hal ini menunjukkan bahwa jika siswa semakin memiliki minat yang besar terhadap kegiatan pembelajaran maka motivasi belajar siswa akan semakin meningkat. Meningkatkan minat belajar dapat dilakukan oleh pihak sekolah dengan cara mengajak para guru dan orang tua untuk dapat menciptakan lingkungan dan kondisi yang nyaman bagi siswa untuk dapat memusatkan perhatiannya, serta bagaimana guru dapat memancing rasa keinginan dan kesukaan yang kuat terhadap suatu pelajaran yang tentunya akan dapat memotivasi keinginan untuk belajar dari siswa.

\section{DAFTAR PUSTAKA}

Adirestuty, Fitranty., \& Eri Wirandana. (2016). Pengaruh Self - Efficacy Guru dan Kreativitas Guru Terhadap Motivasi Belajar Siswa dan Implikasinya Terhadap Prestasi Belajar Pada Mata Pelajaran Ekonomi. SOSIO DIDAKTIKA3,2,158-165. http://dx.doi.org/10.15408/sd.v3i2.4017.

Alfiansyah, Hendita. (2019). The role of parental involvement towards the students' learning motivation. Lentera Pendidikan. Jurnal IImu Tarbiyah dan Keguruan. 22. 276. 10.24252/lp.2019v22n2i9.

Aulia Umami, Desi. (2019). Relationship of learning and interest media towards level imotivation of students widya karsa Jayakarta. Journal Of Midwifery 7,1.

Azma, Hayatul. (2019). Pengaruh Fasilitas Belajar, Minat Belajar, Lingkungan Belajar Dan Motivasi Belajar Terhadap Hasil Belajar Siswa Pada Mata Pelajaran IPS SMK Kabupaten Tanah Datar. Jurnal Ilmiah Universitas Batanghari Jambi 19, 2: 387-390. doi:10.33087/jiubj.v19i2.685.

C.U, Mg Boro., Otubo F.A., \& Uda H.U. (2019). Enhancing Teacher Creativity Using Digital Technology". Journal Of Education And Practice. doi:10.7176/jep/10-27-03.

Gan, Yongtao., \& Sude Bilige. (2019). Parental Involvement In HomeBased Education And Children's Academic Achievement In China". Social Behavior And Personality: An International Journal 47,12: 115. doi:10.2224/sbp.8491.

Ghozali, Imam.,\& Hengky Latan. (2015). Partial Least Squares: Konsep, Teknik dan Aplikasi Menggunakan Program SmartPLS 3.0 (2nd ed.). Semarang: Badan Penerbit Universitas Diponegoro. 
Hair, J. F. Jr., Hult, G. T. M., Ringle, C. M., \& Sarstedt, M. (2014). A Primer on partial Least Squares Structural Equation Modeling (PLS-SEM). SAGE.

Huriyah, Shofiyatul. (2019). An investigation of relationship between the teachers' creativity and the students' motivation in learning English" 5, 2: 239-246.

Karwono, Dr.H., Dr. Heni Mularsih. (2018). Belajar dan Pembelajaran, serta pemanfaatan sumber belajar. Depok: Rajawali Pers.

Kocdar, Serpil., Abdulkadir Karadeniz.,\& Nil Goksel. (2018). Using Facebook For Leveraging Sense Of Community In Self-Paced Open And Distance Learning Courses. International Journal Of Emerging Technologies In Learning (ljet) 13, 05: 100. doi:10.3991/ijet.v13i05.8192.

Kristiyani, Eva dan Iffah Budiningsih. (2019). Pengaruh Strategi Pembelajaran E-Learning dan Minat Belajar Terhadap Hasil Belajar Akuntansi. Jurnal Akademika Teknologi Pendidikan. Vol 8. No.1. doi : https://doi.org/10.34005/akademika.v8i01.341

Lapeniene, Dalia., and Audrone Dumciene. (2013). Teachers' Creativity: Different Approaches And Similar Results". Procedia - Social And Behavioral Sciences, 279-284. doi:10.1016/j.sbspro.2014.01.208.

M Alzoubi, Ahmad., Mohammad F. Al Qudah., Ismael Salameh Albursan., Salaheldin F Bakhiet.,\& Adel S Abduljabbar. (2016). The Effect Of Creative Thinking Education In Enhancing Creative Self-Efficacy And Cognitive Motivation. Canadian Center Of Science And Education 6, 1: $\quad$ 117-130. doi:10.5539/jedp.v6n1p117.

Owusu Amponsah., Mark, Eugene Yaw Milledzi., Eric Twum Ampofo., \& Martin Gyambrah. (2018). Relationship Between Parental Involvement And Academic Performance Of Senior High School Students: The Case Of Ashanti Mampong Municipality Of Ghana". American Journal Of Educational Research 6, 1: 1-8. doi:10.12691/education-6-1-1

Permendikbud. (2020). Peraturan Menteri Pendidikan dan Kebudayaan Republik Indonesia No. 4 Tahun 2020 Tentang Pelaksanaan Kebijakan Pendidikan dalam Masa Darurat Penyebaran Covid-19. Jakarta : Menteri Pendidikan dan Kebudayaan.

Rachmatia, Astrid Natasya dan Khasanah.(2019). Hubungan antara Pemanfaaatan E-journal dan Motivasi Belajar Dengan Kemampuan Pengetahuan Kepustakaan. Jurnal Akademika Teknologi Pendidikan Vol.8 No.2.doi:https://doi.org/10.34005/akademika.v8i02.545

Renninger, K. Ann., Martina Nieswandt., \& Suzanne Hidi. (2015). Interest in Mathematics and Science Learning.

Riswanto, Ari., \& Sri Aryani. (2017). Learning Motivation And Student Achievement : Description Analysis And Relationships Both". COUNS-EDU: The International Journal Of Counseling And Education 2, 1: 42. doi:10.23916/002017026010 
Sardiman, A.M. (2018). Interaksi dan Motivasi Belajar Mengajar. Depok : Rajagrafindo.

Sinem Genc., Zubeyde., \& Fulya Aydin. (2017). An Analysis Of Learners' Motivation And Attitudes Toward Learning English Language At Tertiary Level In Turkish EFL Context. Canadian Center Of Science And Education 10, 4: 35-44. doi:10.5539/elt.v10n4p35.

Slameto. (2015). Belajar dan Faktor-faktor yang Mempengaruhinya. Jakarta: Rineka Cipta.

Yao Tung, Khoe. (2015). Pembelajaran dan Perkembangan Belajar. Indeks :Jakarta. 